\title{
UTILIZATION OF POST-HARVEST TECHNOLOGIES FOR IMPROVED FOOD SECURITY: CASE OF MAIZE AND MANGOES AMONG SMALLHOLDER FARMERS IN KERIO VALLEY, KENYA.
}

\author{
${ }^{1}$ Chepwambok, L.; ${ }^{1}$ Adede, W. O.; ${ }^{3}$ Mugalavai, V.K.; ${ }^{4}$ Onkware, A.O \\ ${ }^{1}$ Department of Agricultural Extension and Education Kisii University, Kenya. \\ ${ }^{3}$ Department of Family \& Consumer Sciences, University of Eldoret, Kenya. \\ ${ }^{4}$ School of Science, Rongo University, Kenya.
}

DOI: 10.46609/IJAER.2020.v06i03.010 URL: https://doi.org/10.46609/IJAER.2020.v06i03.010

\begin{abstract}
Post-harvest management of farm produce determine the quality and quantity of the end product which may affect availability and accessibility of food. The study assessed the utilization of postharvest technologies among smallholder farmers in Kerio Valley Elgeyo Marakwet County, Kenya and their effect on food security. A cross sectional survey was used to collect data on the level of food availability and accessibility of food using a self-administered questionnaire on 217 respondents, an observation checklist and interview schedule. The respondents were categorized as food insecure with an HFIAS score of 5.2. There was a significant positive correlation between the level of food insecurity in the area and the level of post-harvest food losses incurred during threshing $(\mathrm{r}=.329, \mathrm{p}=.03)$ and storage $(\mathrm{r}=.571, \mathrm{p}=.02)$ all at $\mathrm{p}<.05$. This indicates that inadequate and inappropriate use of postharvest technologies led to post-harvest losses thus increased food insecurity in the study area. There is therefore need to capacitate all the players in the food value chain especially in the area of post-harvest management by promoting the use of improved post-harvest and processing technologies. All the stakeholders including government divisions, NGOs, and development partners who specialize in the area of postharvest management should embrace a multi-prong approach to enhancing the food security situation of communities at large.
\end{abstract}

Keywords: Food security, post-harvest losses, post-harvest technologies

\section{INTRODUCTION}

Food security exists when all people, at all times, have physical and economic access to sufficient, safe and nutritious food to meet their dietary needs and food preferences for an active 
and healthy life (FAO, 2011). Consequently, any variation to the state described in the statement above is food insecurity.

Post-harvest handling is the stage of crop production immediately following harvest. The process begins as soon as a crop is removed from the ground, or separated from its parent plant. Postharvest handling to a large extent determines the final quality and quantity of the crop, whether it is sold for fresh consumption or used as an ingredient in a processed food product (Kimiywe, 2015).

Post-harvest losses refer to measurable quantitative and qualitative food loss in the postharvest system (FAO, 2013). The losses comprise of interconnected activities from the time of harvest through crop processing, marketing and food preparation, to the final decision by the consumer to eat or discard the food (Hodges et al., 2011). Postharvest food losses have been associated to food insecurity, especially among the poor people in sub-Sahara Africa because it limits both availability and accessibility (FAO, 2011, Cheger, 2018).

The study focused on two main aspects of food security which is food availability and accessibility. The world food programme (WFP, 2009) defines food availability as amount of food that is present in a country or an area through all forms of domestic production, imports, and food stock and food aid. On the other hand, food accessibility is household's ability to have sufficient amount of food regularly through a combination of purchases, barter, borrowing, food assistance or gifts.

Despite the fact that the smallholder farmers provide over $80 \%$ of the total food consumed in sub-Saharan Africa, post-harvest losses still occur especially at the farm gate where poor harvesting, drying, processing and storage of crops occur (Kimiywe, 2015). The losses are mainly attributed to the absence of efficient technologies and poor post-harvest handling (Godfray et al., 2010). Thus the level of postharvest losses has strong correlation with the available technology (Parfitt et al, 2010). Therefore, one of the strategies to reduce post-harvest losses is to optimize handling of the product at all post-harvest stages (Kitinoja et al., 2011). The study therefore assessed utilization of post-harvest technologies for improved food security.

\section{STUDY AREA}

The study was conducted in Elgeyo Marakwet County (EMC) in Kenya. According to (KNBS 2009, GOK 2010), EMC covers a total area of $3029.9 \mathrm{~km}^{2}$ which constitutes 0.4 percent of the country's total area with a population of 370,712 . The county is divided into three topographic zones namely: the Highlands, the Kerio Valley and the Escarpment. The area along the valley is semi-arid but with high production potential because of fertile soils. Agriculture is the main stay 
activity and a key source of livelihood for the people (County Integrated Development Plan, 2013 Elgeyo Marakwet).

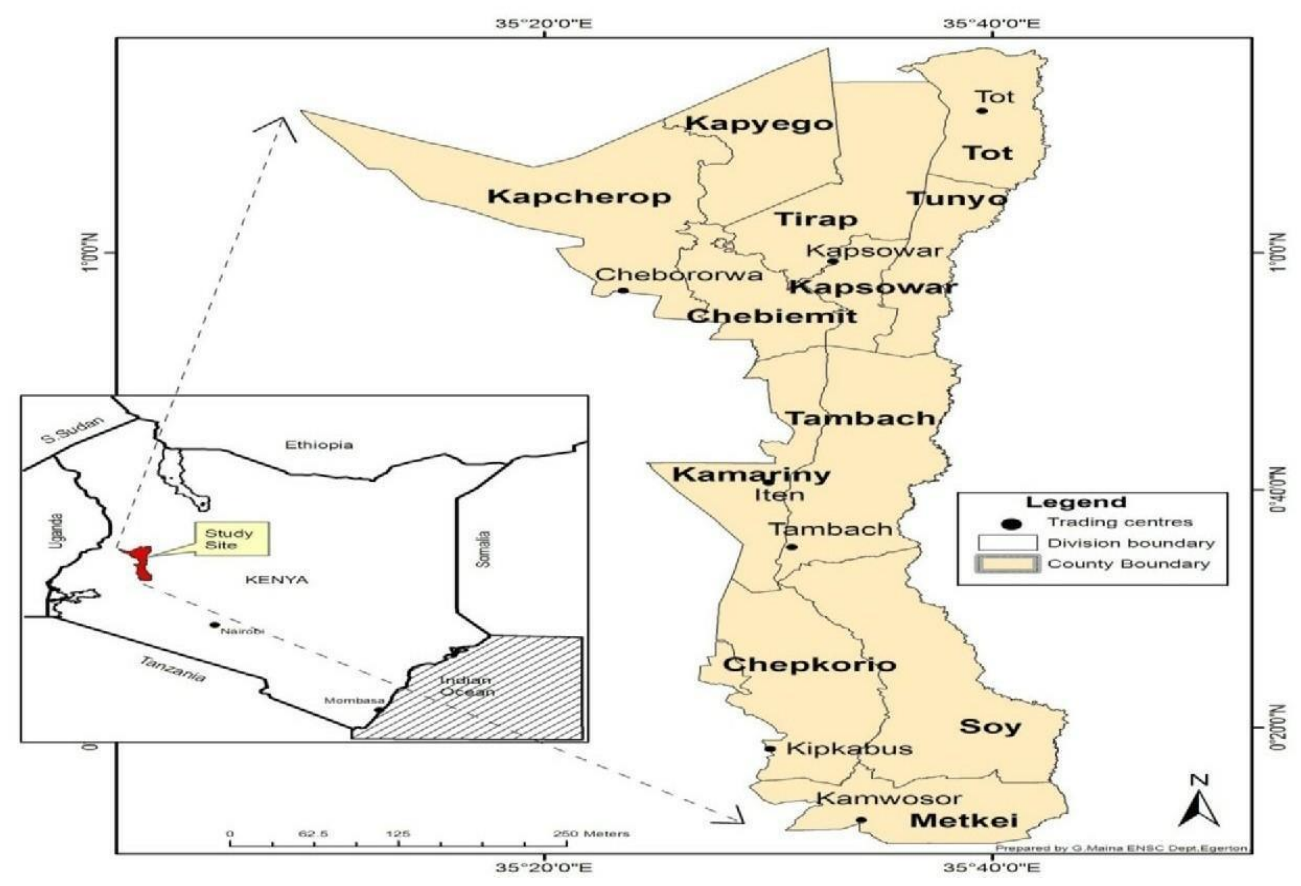

Figure 1: Map of Elgeyo Marakwet

\subsection{Conceptual Framework:}

Food security (availability and accessibility) was dependent on how postharvest handling practices were carried out and also the post-harvest technologies used. However, other factors that would influence the level of food security included, but were not limited to, seasonality in food production and climate change. Following the relationship of these variables, proper postharvest handling practices would likely result to low post harvest losses thus securing the food produce. Similarly availability of appropriate and adequate post-harvest technologies would lead to quality and highly valuable produce. On contrary, if post-harvest handling is poorly carried out accompanied by inappropriate technologies, post-harvest losses would increase and this would result to increased food insecurity. 
Independent variable

\begin{tabular}{|l|}
\hline Post-harvest technologies \\
Post-harvest handling \\
technologies \\
- Harvesting \\
- Transportation \\
- Drying \\
- Threshing \\
Post- Storage \\
processing technologies \\
- Storage facilities \\
- Processing technologies \\
- Preservation
\end{tabular}

Dependent variable

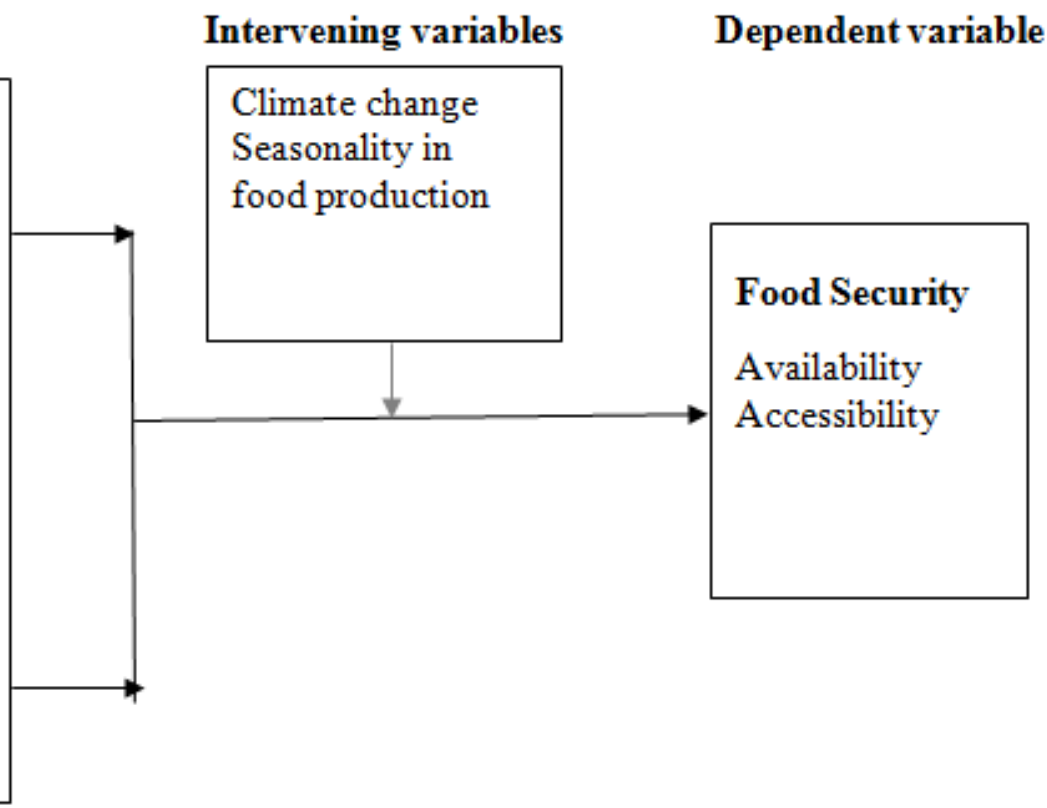

Figure 2: Conceptual framework showing the variables of the study.

\subsection{Methods}

The study adopted cross sectional survey research design. The design was suitable for the study since it provided information on the situation of food security and also the utilization of postharvest technologies. The Target population of the study comprised of both mango and maize farmers in Kerio Valley. A sample size of 217 was randomly selected from three purposively selected wards. The questionnaires were administered to the 217 selected farmers. Direct observation was used to collect information through field surveys to ascertain the response from the farmers and also where the farmers were not certain of some information asked or where the respondents were not willing to answer. Interviews were used to investigate past events which were considered vital to the study.

Data was analyzed using computer software package (SPSS, Version 22). Descriptive and inferential statistics were derived. Analysis of variance was used to determine the difference in food security level by ward. Turkey post hoc test was also carried out to determine the differences between the Ward food security situations whereas Pearson correlation coefficient was used to establish the relationship of food security and food loss. The analysis was done at a confidence level of $95 \%$.

\section{Household food security situation}


International Journal of Agriculture and Environmental Research

ISSN: 2455-6939

Volume: 06, Issue: 03 "May-June 2020"

The household food availability and accessibility situation was derived by screening the respondents to ascertain any level of food insecurity or any signs of hunger. To test food availability and accessibility in the household, Household Food Insecurity Access Scale (HFIAS) score was used. The HFIAS relates to three domain food insecurity which included: - anxiety and uncertainty about household food supply, insufficient quality including variety and preferences of the type of food and insufficient food intake (Coates et al., 2007). The HFIAS scale was used to measure the degree of food insecurity (access) in the household in the past four weeks (30 days). The HFIAS score variable had frequency of occurrence which was coded, for instance, 0 for all cases where the answer to the corresponding occurrence question was "no. The maximum score for a household was 27 (the household response to all nine frequency-of-occurrence questions was "often", coded with response code of 3); the minimum score was 0 (whereby the household responded "no" to all occurrence questions.) The higher the score, the more food insecurity the household experienced. The lower the score, the less food insecurity a household experienced. Experience of food insecurity causes predictable reactions and responses that could be captured and quantified through a survey and summarized in a scale. Households were categorized as increasingly food insecure as they respond affirmatively to more severe conditions or experienced those conditions more frequently. (Radimer et al., 1990, Radimer et al., 1992, Wehler et al., 1992, Hamilton, 1997).

Food availability and accessibility in this case was looked at in terms of a feeling of uncertainty or anxiety over food which entails:-situation, resources, or supply and also the aspect of insufficient food intake which included the number of meals per day, amount of food per meal and also if the household was able to get food whole day and night. Perceptions that food was of insufficient quality asks whether any household member had to eat less than they thought they should (included aspects of dietary diversity, nutritional adequacy and preference) and these focused on physical and economic accessibility of food of different variety and preference by the residents. The food insecurity questions were asked and incase the response was affirmative it was followed by an item on the frequency of occurrence.

A continuous food security scale of $0-10$ was used to measure food security level. The scale measures the severity of food insecurity, and the conditions of being food secure. Food security represented absence of food insecurity indicators thus assigned a scale of zero whereas food insecurity conditions represented presence of all available food insecurity indicators therefore assigned a scale value approaching ten. (USDA, Guide 2000).

\section{RESULTS AND DISCUSSION}

\subsection{Level of food security in the Wards}


The situation of food security per ward is presented in Table 3.1. On the aspect of food uncertainty and anxiety, Arror ward indicated that they are $100 \%$ food uncertain, Tambach (92 $\%)$ followed by Soy $(89 \%)$.

According to food security situation in terms of quantity of food per meal, all households in Arror (100\%), 95\% of Tambach and $68 \%$ of Soy did not have enough food to eat per meal. On the number of meals per day, all the residents of Arror and Tambach (100\%) were not able to eat at least three meals per day, whereas, $48 \%$ of the residents in Soy had fewer than three meals to eat per day. Another item sought to look at the situation of food security in terms of being certain to get at least a meal within 24 hours. In Arror, $80 \%$ of the respondents indicated that they would go without food during the day and night. Whereas $17 \%$ and $41 \%$ of respondents in Soy and Tambach wards respectively would go without food day and night preceding the day.

Table 3.1: Percentage of respondents showing food security situations per ward

\begin{tabular}{|c|c|c|c|c|}
\hline \multirow{2}{*}{ Ward } & Items of food insecurity & \multicolumn{2}{|c|}{$\begin{array}{l}\text { Percentage of respondent } \\
\text { frequency of occurrence }\end{array}$} & \multirow{2}{*}{\begin{tabular}{|l} 
as per \\
$\begin{array}{l}\text { Rarely } \\
(\%)\end{array}$
\end{tabular}} \\
\hline & $\begin{array}{l}\text { Worry that the household } \\
\text { would not get enough food }\end{array}$ & None $(\%)$ & Sometimes (\%) & \\
\hline Arror & & 0 & 79 & 21 \\
\hline Soy & & 11 & 70 & 19 \\
\hline \multirow[t]{2}{*}{ Tambach } & & 8 & 81 & 11 \\
\hline & $\begin{array}{l}\text { Insufficient quantity per } \\
\text { meal }\end{array}$ & & & \\
\hline Arror & & 0 & 20 & 80 \\
\hline Soy & & 32 & 32 & 36 \\
\hline \multirow[t]{2}{*}{ Tambach } & & 5 & 69 & 26 \\
\hline & Fewer meals per day & & & \\
\hline Arror & & 0 & 20 & 80 \\
\hline Soy & & 52 & 16 & 32 \\
\hline
\end{tabular}


International Journal of Agriculture and Environmental Research

ISSN: 2455-6939

Volume: 06, Issue: 03 "May-June 2020"

Tambach

57

43

Households without food

day and night

Arror

Soy

Tambach
20

83

59
37

0

34
43

17

7

$\mathbf{N}=\mathbf{2 1 7}$

To determine the difference in food security per ward, analysis of variance was conducted. There was statistically significant difference in the level of food security among the wards $(P<.001)$ (Table 3.2).

Table 3.2: ANOVA showing the difference in household food security index by ward

\begin{tabular}{lrrrrr} 
& $\begin{array}{l}\text { Sum of } \\
\text { Squares }\end{array}$ & df & $\begin{array}{c}\text { Mean } \\
\text { Square }\end{array}$ & F & Sig. \\
\hline $\begin{array}{l}\text { Between } \\
\text { Groups }\end{array}$ & 80.052 & 2 & 40.026 & 59.06 & .000 \\
$\begin{array}{l}\text { Within } \\
\text { Groups }\end{array}$ & 145.027 & 214 & .678 & & \\
Total & 225.078 & 216 & & & \\
\hline P<.001 & & & & & \\
\end{tabular}

Further analysis was carried out to determine the Ward that was mostly food insecure. Arror Ward was more food insecure. This could mean that more losses were experienced in Arror than in the other wards under study. Therefore proper post-harvest management should be taken into consideration to curb the losses for improved food security situation. 
International Journal of Agriculture and Environmental Research

ISSN: 2455-6939

Volume: 06, Issue: 03 "May-June 2020"

Table 3.3: Post hoc test on household food security by ward

\begin{tabular}{lcccl}
\hline WARDS & $\mathrm{N}$ & \multicolumn{3}{l}{ Subset for alpha $=0.05$} \\
& & 1 & 2 & 3 \\
\cline { 3 - 5 } SOY & 95 & 1.23 & & \\
TAMBACH & 56 & & 1.72 & 2.67 \\
ARROR & 66 & & & 1.000 \\
Sig. & & 1.000 & 1.000 & \\
\hline P $<.05$ & & & &
\end{tabular}

\subsection{Food security situation in Kerio Valley}

The situation of food security in Kerio Valley was summarized in a scale of 0-10 metric as per the responses on household food insecurity access scale scores. The individual household score was divided by the maximum score (20) then multiplied by 10 . The resulting scores were categorized based on the classification scale as shown below.

Table 3.4: Categorized Household Food Security Status according to HFIAS scores

\begin{tabular}{|c|c|l|l|}
\hline $0-2.5$ & $2.6-5.0$ & $5.1-7.5$ & $7.6-10$ \\
\hline \multirow{2}{*}{ Food Secure } & \multicolumn{3}{|c|}{ Food insecure } \\
\cline { 2 - 5 } & $\begin{array}{l}\text { mildly food } \\
\text { insecure }\end{array}$ & $\begin{array}{l}\text { moderately } \\
\text { food insecure }\end{array}$ & $\begin{array}{l}\text { severely food } \\
\text { insecure }\end{array}$ \\
\hline
\end{tabular}

Food secure (no/ minimal evidence of food insecurity)

Mildly food insecure (food insecurity without huger)

Moderately food insecure (food insecurity with hunger- reduced food intake)

Severe food insecure (food insecurity with hunger- extensive reduction in food intake) 
Calculation of household food insecurity access scale (HFIAS)

$$
\begin{gathered}
\text { HFIAS }=\frac{\text { Sum of the household score in the sample }}{\text { The number of household in the sample }} \\
\text { Average HFIAS }=\frac{2230}{217}=10.28 \\
10.3 / 20 * 10=5.2
\end{gathered}
$$

From the results above, a score of 5.2 was obtained and Kerio Valley was categorized as moderately food insecure thus an implication that the households experienced food insecurity with reduced food intake.

\section{Post-harvest losses of maize and mangoes attributed to post-harvest handling processes}

\section{(A) Maize}

\subsubsection{Harvesting}

During harvesting the grain is very susceptible to pest attacks since it is harvested at physiological maturity when the moisture content is high (20-30\%). Also, rains at this stage dampen the crop, resulting in mold growth and the associated risk of aflatoxin or other mycotoxin contamination (World Bank, 2010). Harvesting was done manually where the maize cobs were thrown on the ground then collected thereafter before being transported for storage. During this process grains were broken, some spilled to the ground and other were contaminated leading to losses which farmers never realized. The total average losses during harvesting was 15.3\% with Arror registering a mean loss of $16.7 \%$, Soy $16.2 \%$ and Tambach $12.4 \%$.

\subsubsection{Transport}

Transportation of maize was done after harvesting the grain. Most farmers (69\%), carried their produce manually (on their heads, shoulders, and backs). This was mainly because most of the homes were inaccessible due to the terrain of the region and poor road network. Thirty one (31 $\%)$ used tractors. The average losses during transit of maize was $6.3 \%$.

\subsubsection{Drying}

Sun drying was done to reduce the moisture content of the produce. It was done by spreading the produce on mats before they were stored. During this process an average of 5 percent loss was experienced and this was associated to spilling and presence of already broken and rotten grains. The results were in line with the report by World Bank (2010) where it was reported that most farmers, both small and large, relied almost exclusively on natural drying of crops from a 
combination of sunshine and movement of atmospheric air through the product. Grains should be dried in such a manner that damage to the grain is minimized and moisture levels are lower than those required to support mold growth during storage (usually below $15 \%$ ).

\subsubsection{Threshing}

During threshing an average loss of $5.4 \%$ was experienced for maize. The losses were in terms of broken grains and spillage because most farmers $(84 \%)$ threshed their produce by beating them in bags. Sixteen (16\%) used grain shellers but then it would still lead to losses. The method of shelling can affect the produce quality as well as predispose it to further deterioration. The damages from these operations were linked to moisture content of the grain and the method used (Dudi, 2014). An average of $5 \%$ was experienced when hand was used for threshing whereas 7.6 $\%$ loss when grain shellers were used. This indicated that more losses were incurred when machines were used than when maize were beaten by hand. This could be because of more spillage and unshelled maize remaining in the cobs caused by inefficiency of the shelling machine. The results were presented in Table 3.5 below.

Table 3.5: Average losses of maize during post-harvest handling process

\begin{tabular}{|c|c|c|c|c|c|}
\hline Wards & $\begin{array}{l}\text { Harvesting } \\
(\%)\end{array}$ & $\begin{array}{l}\text { Transporting } \\
(\%)\end{array}$ & $\begin{array}{l}\text { Drying } \\
(\%)\end{array}$ & $\begin{array}{l}\text { Threshing } \\
(\%)\end{array}$ & $\begin{array}{l}\text { Method of threshing } \\
\text { \& average losses }\end{array}$ \\
\hline $\begin{array}{l}\text { Arror } \\
(n=66)\end{array}$ & 16.7 & 7.7 & 6.5 & 7 & $\begin{array}{l}\text { Hand } \quad(n=184) 5.0 \\
\text { beating }\end{array}$ \\
\hline $\begin{array}{l}\text { Soy } \\
(n=95)\end{array}$ & 16.2 & 6.2 & 4.2 & 5 & $\begin{array}{l}\text { Grain } \\
\text { shellers }\end{array}$ \\
\hline $\begin{array}{l}\text { Tambach } \\
(\mathrm{n}=56)\end{array}$ & 12.4 & 4.7 & 5.4 & 4 & \\
\hline $\begin{array}{l}\text { Total } \\
\text { average } \\
\text { losses }\end{array}$ & 15.3 & 6.25 & 4.9 & 5.4 & \\
\hline
\end{tabular}

$\mathbf{N}=\mathbf{2 1 7}$ 


\subsubsection{Storage}

The type of storage facility and material used can preserve or cause deterioration of the produce (Dudi, 2014). The type of produce that was stored for a long period of time was mainly the cereals including maize. From the results it was indicated that majority of farmers stored their maize in traditional granaries $(53.3 \%)$ followed by those who stored their maize in the living houses $(47.9 \%)$. The results of this study supported the finding by Bett and Nguyo (2007) which indicated that majority of farmers $(49 \%)$ stored their maize in traditional granaries whereas $41 \%$ of them stored the same in the living rooms. Twenty nine (29\%) stored maize in cribs, $4 \%$ on baskets and none used silos for storage.

The average loss of maize during storage was $6.5 \%$ with Arror recording an average of $7 \%$ whereas Soy and Tambach recorded an average of $6 \%$ each. Higher losses (6.9\%) were reported on grains stored in cribs and less losses $(5.8 \%)$ on grains kept in the living room. The results concurred with that of Komen et al (2006) and Nduku et al (2013) that lower losses are incurred when grains are kept in the house because of close monitoring and higher in the cribs due to insect infestation and the condition of the storage structure. Table 3.6 below presented storage facilities used by farmers, average losses of maize during storage and losses associated to storage facilities.

Table 3.6: Average losses of maize during storage and types of storage facilities used.

\begin{tabular}{lllll}
\hline Wards & $\begin{array}{l}\text { Average losses }(\%) \\
\text { of maize during } \\
\text { storage per ward }\end{array}$ & $\begin{array}{l}\text { Storage } \\
\text { facility }\end{array}$ & $\begin{array}{l}\text { Percentage } \\
\text { of } \\
\text { respondents }\end{array}$ & $\begin{array}{l}\text { Average loss } \\
\text { associated to } \\
\text { storage facility } \\
\text { used }\end{array}$ \\
\hline Arror & 7 & cribs & 29 & $(\mathrm{n}=50) 6.9$ \\
Soy & 6 & living room & 47.9 & $(\mathrm{n}=59) 5.8$ \\
Tambach & 6 & granary & 53.3 & $(\mathrm{n}=108) 6.6$ \\
$\begin{array}{l}\text { Total } \\
\text { loss }\end{array}$ & 6.5 & baskets & 4 & \\
& & Silos & 0 & \\
\hline
\end{tabular}

N=217; NB: Multiple responses allowed. 
International Journal of Agriculture and Environmental Research

ISSN: 2455-6939

Volume: 06, Issue: 03 "May-June 2020"

\section{(B) Mangoes}

The lands size under mango production was been reported to be on the increase every year (HCDA, 2011). However, despite the increase in production, losses of mangoes have been reported to be huge and during post-harvest handling. During this study, it was noted that farmers used various methods of harvesting their produce. Most farmers climb up the mango trees to manually harvest the fruits at physiological maturity to reduce physical damage to the fruits. However, some farmers used sticks whereas others shook the tree for the fruit to fall on the ground which caused bruising or even complete damage and increased losses. The average losses of mangoes during harvesting was recorded at $16.1 \%$ with Arror experiencing an average loss of $18 \%$, Soy $16 \mathrm{p} \%$ and Tambach $13 \%$ loss. Most of the farmers (44.3\%) associated the losses to bruises due to poor handling, $29 \%$ reported that the losses were caused by diseases and pests and $26.7 \%$ associated the losses to falling of the fruits leading to bursting.

The study further showed that apart from surplus of the produce during the peak period, the wet season also was associated with increased losses. To avoid a total loss farmers preferred to sell their produce at low prices and the fact being that they were smallholder producers, they depended largely on local traders for market information leading to low and unpredictable prices (Mulinge, 2015). Due to poor transport network farmers were forced to wait for traders to come and buy the fruits from their homestead, and this led to many through spoilage. Moreover, the farmers did not had good storage. A few farmers however could transport their fruits to the nearest market or to sell them at the road-side. The traders used various types of trucks to transport the produce to the market and in the course of transit, a lot of mangoes were crushed and bruised. An average loss of 5.6 \% was recorded when Lorries were used for transport and 5.2 $\%$ loss when motorbikes were used. This could be associated to the number of layers loaded and also compression during transit. On the other hand farmers who carried the produce themselves to the market experienced minimal losses (4.2\%) compared to those who used trucks and motorbikes leading to average losses of $5.0 \%$. This could be linked to the quantity of mangoes carried by an individual where there was less compression of the fruits. In case of surplus, the mangoes were left to drop and rot on the ground and others eaten by birds leading to a big loss. Table 3.7 below showed the average losses of mangoes during harvesting and transportation processes. 
International Journal of Agriculture and Environmental Research

ISSN: 2455-6939

Volume: 06, Issue: 03 "May-June 2020"

Table 3.7: Average losses of mangoes during harvesting and storage

\begin{tabular}{|c|c|c|c|c|c|}
\hline wards & $\begin{array}{l}\text { Transport } \\
\text { losses (\%) }\end{array}$ & $\begin{array}{l}\text { Harvesting } \\
\text { losses (\%) }\end{array}$ & $\begin{array}{l}\text { Causes of } \\
\text { losses } \\
\text { during } \\
\text { harvesting }\end{array}$ & & $\begin{array}{l}\text { Losses } \\
\text { associated } \\
\text { to mode of } \\
\text { transport } \\
\text { used }\end{array}$ \\
\hline Arror & 5.7 & 18 & $\begin{array}{l}\text { Bruises due } \\
\text { to poor } \\
\text { handling }\end{array}$ & $(\mathrm{n}=96) 44.3$ & $(n=83) 5.6$ \\
\hline Soy & 4.9 & 16 & $\begin{array}{l}\text { Diseases and } \\
\text { pests }\end{array}$ & $(n=63) 29$ & $(\mathrm{n}=97) 5.2$ \\
\hline Tambach & 4.4 & 13 & Falling & $(\mathrm{n}=58) 26.7$ & $(\mathrm{n}=37) 4.5$ \\
\hline $\begin{array}{l}\text { Total } \\
\text { average loss }\end{array}$ & 5.0 & 16.1 & & & \\
\hline
\end{tabular}

\section{$\mathbf{N}=\mathbf{2 1 7}$}

\subsection{Household food security and post-harvest losses}

The technologies practiced by farmers were mainly the critical and frequently used post-harvest processes. These post-harvest technologies included storage, processing, and preservation. A majority of farmers threshed their maize by beating in bags, although a few used the maize shelling machines. Table 3.8 presents the results of a correlation between food security and losses incurred during the process of threshing.

Table 3.8: Relationship between household food security and losses during threshing

\begin{tabular}{lcc}
\hline & Value & Sig. (2-tailed) \\
\hline Pearson Correlation & .329 & .03 \\
Spearman's rho & .669 & .000 \\
\hline $\mathrm{P}<.05$ & &
\end{tabular}

There was significant relationship between food insecurity and losses during threshing ( $\mathrm{r}=.329$ and $P=.03$ ). Losses were less where manual shelling was used and high where shelling machine 
was used. The results concurred with the findings by Dudi (2014). This may be attributed to poor drying of maize before shelling where a majority of farmers carried out threshing shortly after harvest at moisture level of above $25 \%$ and also the efficiency of shelling machine used. This therefore necessitated an intervention that would reduce losses at shelling by using more appropriate and efficient technology.

The relationship between food security and losses during storage was also established using 2 tailed Pearson's correlation. Table 3.9 presents the results of a correlation between food security and losses during storage. There was a strong correlation between food insecurity and losses during storage $(\mathrm{r}=.571$ and $P=.002)$. These showed that storage was done to already injured grains and also the nature of packaging materials used since most of the farmers used plastic bags which are likely to have high moisture when used for long (Dudi, 2014). The few farmers who used chemicals for preservation did not use the recommended rates of application or applied the insecticide at the wrong time leading to attack by pests and molds.

Table 3.9: Relationship between Food security and losses during storage.

\begin{tabular}{llc} 
& Value & Sig. (2-tailed) \\
\hline Pearson Correlation & .571 & .002 \\
Spearman's rho & .757 & .000 \\
\hline $\mathrm{P}<.05$ & &
\end{tabular}

\section{CONCLUSIONS AND RECOMMENDATIONS}

The residents of Kerio Valley were found to be food insecure. Among the three wards, Arror ward was found to be more food insecure indicating up to 100 percent incidents of food insecurity.

In addition there was significant relationship between food insecurity and losses incurred at different management processes. This showed that inadequate and inappropriate use of technologies led to losses, food insecurity and consequently poverty. Existing projects in Elgeyo Marakwet County have tended to focus on increasing production yet even what is currently produced would still be sufficient if well managed. The marked food insecurity and poverty levels in Elgeyo Marakwet County are largely attributed to post-harvest handling losses due to both inappropriate and less efficient technologies and lack of any technology for food preservation, value addition and agro processing (County Integrated Development Plan 2013, Elgeyo Marakwet). 
International Journal of Agriculture and Environmental Research

ISSN: 2455-6939

Volume: 06, Issue: 03 "May-June 2020"

It is recommended that there should be a focus on curbing post-harvest losses by means of good processing, storage and market information technologies. Research that focuses on the small scale cottage industries for food processing, food fortification and value addition would be very handy.

\section{REFERENCES}

Bett, C. \& Nguyo, R. (2007). Postharvest storage practices and techniques used by farmers in Eastern and Central Kenya. Journal of African crop science society 8: 1023-1227.

Brickel Gary, Mark Nord, William Hamilton, Cristofer Price and John. Cook. Guide To Measuring Household Food Security. USDA, Guide 2000.

Cheger. M. (2018). Post-Harvest Losses Reduction by Small-Scale Maize Farmers: Role of Handling Practices, Food Policy, 103-115.Doi10:10161, Foodpol.2018.02.001.

County Government of Elgeyo Marakwet, (2013). County Integrated Development Plan 2013 2017, 296 pp).

Coates Jennifer, Anne Swindale and Paula Bilinsky. (2007). Household Food Insecurity Access Scale (HFIAS) for Measurement of Household Food Access: Indicator Guide (v. 3). Washington, D.C.: FHI 360/FANTA.

Dudi, J. A. (2014). Assessment of Post-Harvest Grain Management Operations and their Effects on Food Security of Smallholder Households in Kisumu County, Kenya.

FAO (2011). The Global Food Losses Report 2011, commissioned by the United Nations Food and Agriculture Organization (FAO).

FAO, (2013). Food wastage footprint: Impacts on natural resources.

Gathambiri, C. W., Muchui, M. N., Njuguna, J. K., Wepukhulu, S. B., Kiiru, S. N., Wanjala, S. N. \& Kariuki, D. N. (2006). Evaluation of postharvest characteristics of mango fruit. 10th KARI Biennial Scientific Conference proceedings, pp 1-3.

Godfray HCJ, Beddington JR, Crute IR, et al. (2010) Food security: The Challenge of Feeding 9 Billion People. Science 327, 812-818.

GoK (2010). 2009 Population and Housing Census Results. Nairobi: Kenya National Bureau of St, Ministry of Planning, National Development and Vision 2030.

Hamilton, William L., John T. Cook, William W. Thompson, Lawrence F. Buron, Jr. Edward A. Frongillo, Christine M. Olson, and Cheryl A. Wehler. "Household food security in the 
International Journal of Agriculture and Environmental Research

ISSN: 2455-6939

Volume: 06, Issue: 03 "May-June 2020"

United States in 1995: Summary report of the food security measurement project." Washington, D.C.: United States Department of Agriculture, 1997.

Hodges, R., Bennett, B., Mwebaze, P. \& Stathers, T. (2010). Postharvest loss (PHL) reduction for cereal grain staples in Sub-Saharan Africa. In: Traoré, M (Ed).Technical meeting on lessons learned and practical guidelines on achieving postharvest improvements in grain supply chains in Africa 18 - 19 March 2010, Rome.

Horticultural Crops Development Authority (2010). Food Quality Annual Report, HCDA. Nairobi: Kenya.

Kimiywe, J. (2015). Conference on "Food and nutrition security in Africa : new challenges and opportunities for sustainability" Food and nutrition security: challenges of post-harvest handling in Kenya Proceedings of the Nutrition Society Proceedings of the Nutrition Society, (August 2015), 487-495. https://doi.org/10.1017/S0029665115002414.

Kitinoja. L., Saran, S.S., Roy, S.K., \& Kader, A.A. (2011).Post-harvest technology for developing countries: Challenges and Opportunities in Research; Outreach and Advocacy, 597-603. Doi/10.1002/jsfa.4295.

Komen, J.J., Mutoko C.M.,Wanyama J.M., Rono S.C. and Mose.L.O., (2006).Economics of Post-Harvest Maize Grain Losses in Trans-Nzoia and Uasin Gishu Districts of North West Kenya. Kenya Agricultural Institute, Kitale

Kombo, Tromp (2006).Sample Determination, New analysis procedures ISBN 32/322 Nairobi University Publishers: Nairobi.

Mulinge, W. K. (2015). Grafted mangoes enhances smallholder farmers livelihoods in Matinyani Division, Kitui County, 5(16), 60-65.

Nduku. T.M., De Groote., Jonathan. N.M., (2013). Comparative analysis of maize storage structures in Kenya. International Maize and Wheat Improvement Centre (CIMMT). Nairobi, Kenya.

Parfitt, J., Barthel, M., \& McNaughton, S. (2010). Food waste within food supply chains: quantification and potential for change to 2050, 3065-3081. https://doi.org/10.1098/rstb.2010.012.

Radimer, K. L., C. M. Olson, and C. C. Campbell. "Development of indicators to assess hunger." Journal of Nutrition 120:11 1544-1548, 1990. 
Radimer, K. L., C. M. Olson, J. C. Greene, C. C. Campbell, and J. P. Habicht. "Understanding hunger and developing indicators to assess it in women and children." Journal of Nutrition Education 24:1 S36S44, 1992

The Rockefeller Foundation (2015).Perspectives To Reduce Post-Harvest Losses of Agricultural Products in Africa.

Wehler, C., R. Scott, and J. Anderson. "The community childhood hunger identification project: A model of domestic hunger -- demonstration project in Seattle, Washington." Journal of Nutrition Education 24: 29S-35S, 1992.

World Bank (2010). Missing Food. The case of post-harvest grain losses in Sub-Saharan Africa. Washington, DC; the World Bank.

World Food Programme (WFP). (2009). Emergency food security assessment Handbook. Africa. Washington, DC; the World Bank. 